\title{
Football DATACO v Sportradar. defining where making available takes place and its implications
}

\author{
Football Dataco Ltd and others $v$ Sportradar GmbH and \\ another [2010] EWHC 2911 (Ch); [2010] WLR (D) 293, Ch D: \\ Floyd J: 17 Nov 2010.
}

\section{Gaetano Dimita}

Centre for Commercial Law Studies, Queen Mary University of London

The act of making available to the public all or a substantial part of the contents of a database by online transmission is committed, and committed only, where the transmission takes place.

\section{LEGAL CONTEXT}

There is no international or regional agreement on the scope and application of the right to make available. For instance, it is not clear which acts are involved in making available, how materials have to be placed online in order to be made available, who makes available on-demand, when and where. Litigation against infringers could ultimately fail on the fact that the above parameters are questionable. However, there have been decisions at national level and Football Dataco v Sportradar clarifies some issues in the UK in relation to where making available takes place.

Generally, it could be argued that making available takes place in all or any of the places where the uploader uploaded, the server or the internet server provider is based, and/or at the reception point. As with broadcasting, the two main theories in relation to this point are the emission theory, which briefly states that the communication takes place at the point of initial transmission, and the communication theory, developed from the Bogsch Theory, which stated that the act of communication embraces the whole process of transmission and reception.

Notwithstanding authoritative texts supporting the approach that the communication to the public in the internet context has to be seen as one process involving initiation and reception (communication theory), rather than as related primarily to the point of initial transmission (emission theory), ${ }^{1}$ Floyd $\mathrm{J}$ held that the act of making available to the public is committed only where the transmission takes place.

1. See JAL Sterling, World Copyright Law, 3rd edn (Sweet \& Maxwell 2008); J Reinbothe and S von Lewinski, The WIPO Treaties 1996 (Butterworth's 2002) 108-09; M Ficsor, 'The Law of Copyright and the Internet (OUP 2002) 405. But see also Copinger and Skone James on Copyright, 15th edn (Sweet \& Maxwell, 2005) para 7-117. 


\section{FACTS AND ANALYSIS}

The case concerns the alleged infringement of copyright and database right on an internet site in Germany accessible in the United Kingdom; and, in particular, an application by the defendants for an order declaring that the court had no jurisdiction. In order to address this issue, Floyd J. had to consider, along with other matters, whether and where re-utilization of the contents of a database had taken place (Article 7(2)(b) Database Directive), and at Para 63 of the judgment he raised the question:

Where does 'making available to public all or a substantial part of the contents of a database by ... online ... transmission' occur?

He concluded at para. 74:

I have come to the conclusion that the better view is that the act of making available to the public by online transmission is committed and committed only where the transmission takes place. It is true that the placing of data on a server in one state can make the data available to the public of another state but that does not mean that the party who has made the data available has committed the act of making available by transmission in the State of reception. I consider that the better construction of the provisions is that the act only occurs in the state of transmission.

This can be interpreted as an acceptance of the emission theory. However, notwithstanding this, para. 74 clearly refers to online transmission being committed only 'where the transmission takes place'; it is questionable whether the reference is to the place of initial transmission or to transmission generally. This second interpretation would include the initial as well as the subsequent transmission (transmission from the uploader to the site, from the site to the accessor, etc. - Bogsch theory).

Precedent authorities supported the view that, in the context of the WIPO Treaties 1996 and the Information Society Directive, 'making available' embraces availability at the point of initial transmission and at the point of reception. Moreover Section 6(4) CDPA (the place from which a broadcast is made is the place from which the programme-carrying signals are introduced into an uninterrupted chain of communication) does not mention online transmission, and, with exceptions, internet transmission is excluded from the definition of broadcasting (Section 6(1A)).

The judge decided not to refer any question to the Court of Justice of the European Union, as a reference to the Court in the circumstances of the case was deemed unnecessary. It is thought, however, that the Court of Justice of the European Union, if questioned, would probably make reference to Recitals 20, 23 and 24 of the Information Society Directive, which could be interpreted in contrast with the emission theory. These references, however, do not appear in the present judgment.

The judge concluded that the court had jurisdiction over the claim for authorizing, and joint liability for, copyright infringement and the claim for joint liability for infringement of the database right. He also allowed the amendments to save the claim under Section 20 of the Act to be limited to the claims over which the court has jurisdiction.

\section{PRACTICAL SIGNIFICANCE}

This decision referring to the point of initial transmission as the place where making available takes place may strongly limit the extension and applicability of the making 
104 Queen Mary Journal of Intellectual Property, Vol. 1 No. 1

available right not only in determining where, but also who and when protected material is made available, in particular in those cases in which the point of origin is unknown or when there are multiple points of origins in multiple jurisdictions. Consequently, it could be argued, for instance, that linking to infringing content from another jurisdiction may no longer be making available in the UK, as well as file sharing from another jurisdiction or storing infringing content on a cloud server based in a foreign country.

Debate on this decision will undoubtedly take place at national, international and regional levels, given the implications of the decision as to the application of the making available right, in particular for licensing and damages. 